\title{
President's Report 2017
}

\section{Introduction and thanks}

My term as President begin in January 2017. Pauline Mellon's term as Vice-President began at the same time. I would like to thank my predecessor, Michael Mackey, for his leadership and hard work during his term of office. He did an excellent job of representing the Society, and he helped to make the transition very smooth.

The new members of the Committee for 2017 are Pauline Mellon and Dana Mackey, replacing outgoing members Michael Mackey and Martin Mathieu, both of whom I would like to thank for their dedicated work on the Committee during the previous six years.

I wish to record the Society's thanks to Anthony O'Farrell for his ongoing excellent work as editor of the IMS Bulletin. Thanks also go to the other members of the Bulletin team: Ian Short (problem page maintainer), Gordon Lessells (who oversees printing and distribution), and the Editorial Board (Anthony O'Farrell, Tom Carroll, Jim Cruickshank, Ian Short, and Thomas Unger).

Finally, I would also like to thank Richard Timoney for maintaining the Society's webpages.

\section{IMS meetings and IMS-supported meetings}

The Society's 2017 "September meeting" was held at IT Sligo (31 August-1 September). As usual, this functioned as both the main scientific meeting of the Society and its AGM. Special thanks go to the main organiser, Leo Creedon, for organising this event. The 2018 "September meeting" will be held in UCD.

The Committee also met on 19 December in Queen's University Belfast. That meeting was followed immediately by the IMS Invited Lecture Temporal Profiles of Avalanches on Networks, given by James Gleeson. It is my hope that future end-of-year Committee meetings can also be followed by invited lectures.

The Society supported the following meetings held during 2017:

- Minimal surfaces: Integrable systems and visualisation, UCC: March 27-29.

- CERME 10, DCU: February 1-5.

- The 14th Annual Workshop on Numerical Methods for Problems with Layer Phenomena, NUIG: April 6-7. 
- Groups in Galway, NUIG: May 18-20.

- Irish Geometry Conference 2017, Maynooth University: May 25-26.

- 6th National Student Chapter Conference of the UK and Ireland Section of SIAM, NUIG: May 26.

- 3rd Irish Linear Algebra and Matrix Theory Meeting, Maynooth University, September 8.

- 11th Annual Irish Workshop on Mathematics Learning and Support, North West Regional College, Derry: December 1.

It was a difficult task to choose which meetings to support. Thanks go to the Treasurer, Goetz Pfeiffer, for efficiently overseeing the application process, and for making the task of deciding on funding less onerous.

\section{EMS Meetings of Presidents}

I represented the Society at the annual Meeting of Presidents held by the European Mathematical Society. This year's meeting was on 1-2 April in Lisbon. It was a useful opportunity to discuss matters of mutual interest with other national mathematical society presidents and representatives. The main discussion on 2 April concerned open access publication. Various documents, including a report on the meeting, can be found at http://ems2017.spm.pt/

I accepted an invitation to hold the next Meeting of Presidents in Ireland. That meeting will be held at Maynooth University, 14-15 April 2018.

\section{Education Subcommittee}

The Education Subcommittee has been working very actively on a number of matters throughout the year, and I would like to thank it for its hard work. As a result of a recommendation from the Subcommittee, I wrote to the National Council for Curriculum and Assessment (NCCA), seeking to add at least one more academic mathematician to the membership of the Mathematics Development Group (MDG). (The MDG is a committee that was formed to advise the NCCA on matters relating to Mathematics, and it is currently working on a revised Applied Mathematics curriculum. David Wraith was the only third level mathematician on the MDG as of early 2017.) Thanks to pressure from ourselves and other sources, the NCCA approved James Gleeson as an additional member of the MDG. 
Another initiative of the Subcommittee resulted in the formulation of a Short Guide to Second-Level Maths. This webpage on the IMS website contains a first introduction to the structure of mathematics education in the Irish second-level education system, together with various useful links relating to curriculum and exams. As a source of detailed information on what mathematics is taught at second level in Ireland - bearing in mind that the curriculum has undergone significant changes in recent years because of the roll-out of the new "Project Maths" syllabus - this page should be of interest to all IMS members working in Irish third level institutions, as well as colleagues in other science departments.

S. Buckley

December, 2017

E-mail address: sbuckley@nuim.ie 